Case Report

\title{
Strategizing Smart, Sustainable, and Knowledge-Based Development of Cities: Insights from Florianópolis, Brazil
}

\author{
Jamile Sabatini-Marques ${ }^{1}$, Tan Yigitcanlar ${ }^{2}{ }^{\mathbb{D}}$, Tatiana Schreiner ${ }^{1}$, Tatiana Wittmann ${ }^{1}$, \\ Debora Sotto ${ }^{3}$ and Tommi Inkinen $4, *$ (i) \\ 1 Department of Engineering and Knowledge Management, Federal University of Santa Catarina, \\ Campus Universitario, Trindade, Florianópolis, SC 88040-900, Brazil; jamile.sabatini@abes.org.br (J.S.-M.); \\ tati@labchis.com (T.S.); tatianaw@labchis.com (T.W.) \\ 2 School of Built Environment, Queensland University of Technology, 2 George Street, \\ Brisbane, QLD 4000, Australia; tan.yigitcanlar@qut.edu.au \\ 3 Institute of Advanced Studies, University of São Paulo, R. do Anfiteatro, 513, Butantã, \\ São Paulo, SP 05508-060, Brazil; dsotto@usp.br \\ 4 Faculty of Science and Engineering, University of Turku, 20014 Turku, Finland \\ * Correspondence: tommi.inkinen@utu.fi; Tel.: +358-400-882-818
}

Received: 6 October 2020; Accepted: 24 October 2020; Published: 25 October 2020

\begin{abstract}
Unarguably, smart, sustainable, and knowledge-based development is critical for securing a livable future for our rapidly urbanizing world. The aim of this study is to generate insights into determining effective and efficient strategies to increase sustainability and innovation capabilities of cities to achieve long-term desired urban outcomes. This paper places the city of Florianópolis (Brazil) under the smart, sustainable, and knowledge-based urban development microscope. The methodological approach of the study involves a qualitative analysis through surveys (100 submitted forms, 55 responses received) and interviews (12) with key experts and stakeholders from Florianópolis. The findings of the study reveal that Florianópolis' innovation ecosystem has high potential to thrive, but the city still has structural issues to deal with first, related to the gap between the potential to grow, and acknowledgement from key actors of the city to support the overall territory development considering the complex dimensions. This issue suggests amplifying the ecosystem's vision, including different sectors and, especially, addressing innovation for the common good. The insights generated from the investigation of Florianópolis' case are also invaluable to other cities' planning for strategizing their transformation, and seeking smart, sustainable, and knowledge-based development pathways.
\end{abstract}

Keywords: smart city; smart urbanism; smart and sustainable urban development; sustainable development; knowledge-based urban development; urban governance; urban transformation; innovation; Florianópolis; Brazil

\section{Introduction}

Smart, sustainable, and knowledge-based urban development (KBUD) is the catchphrase of our time, as the whole world struggles with climate, pandemic, and financial emergencies [1,2]. Particularly, in the case of emerging economies, this has had a severe impact for Brazil, among others [3-5]. In this case report, we placed an emerging innovation capital of Brazil, namely Florianópolis, under the microscope to generate insights for determining effective and efficient strategies to increase sustainability and innovation capabilities of cities to achieve long-term desired urban outcomes in the age of climate, pandemic, and financial catastrophes. 
Florianópolis is the capital of the Brazilian southern state of Santa Catarina. Mostly located in the Santa Catarina Island, Florianópolis has a population of approximately half a million inhabitants [6], a per capita GDP of R 40,162 (around USD 7452) [7] and a Human Development Index of 0.847, the third best city in Brazil [8]. Thanks to its coastal and isolated nature and subtropical climate, the city is a popular tourist destination for both Brazilians and South American travelers.

Around the 1980s, the city started looking for alternatives to tackle its evident economic growth limitations. As its territory is mostly insular, Florianópolis could only offer employment in the public, retail, fishing, and tourism sectors, as industrial developments were, and still are, strictly forbidden by environmental regulations. Through federal, state, and municipal incentives, and taking advantage of the presence of high-quality universities, mostly focused on engineering, the technology sector was established as a viable form of development that coupled with environmental concerns while bringing high added value and generating employment and income. In these circumstances, in the 1980s, two important institutions were founded in Florianópolis to foster an ecosystem of technology and innovation, i.e., Centers of Reference in Innovative Technologies Foundation (CERTI) and the Technology Association of Santa Catarina (ACATE).

During the 1990s, a significant number of software companies, a technological park, ParqTec Alfa, and two incubators, CELTA and MIDI, were established in Florianópolis. A few years later, in 2006, an innovation center, named Sapiens Park, was established in the city as a joint initiative from the state government and the CERTI Foundation. As a result of the joint efforts conducted by the state and city government, universities and entrepreneurs, the city successfully established itself as an innovation center in the late 2000s, thus, recognized both in Brazil and abroad. Currently, the technology sector in Florianópolis generates over R 4.3 billion (around USD 798 million) in revenue per year and employs more than 17,000 people [9]. According to the 2020 edition of the Connected Smart Cities Ranking, which maps the cities with the greatest development potential in Brazil, Florianópolis was ranked as the second most intelligent and connected city in the country [10]. The city won third place in the economy category, in addition to fourth place in the technology and innovation category, fifth place in mobility and accessibility, seventh place in entrepreneurship and health, and 10th in security in the same ranking [10]. Florianópolis was also ranked as the second best entrepreneurial ecosystem amongst the major cities in Brazil, according to the Entrepreneur Cities Index [11].

Local tax exemptions and incentives and public policy programs set up by the Municipal Law of Innovation, issued in 2012, have played, and still play, an important role in Florianópolis economic transition to technology and innovation. A Municipal Innovation Council (CMI) was established as the main managing body of innovation policy and, since 2007, the city mobilized the local innovation ecosystem through the so-called "Innovation Promotion Arrangements (API)", aimed to fund selected projects with both public and private resources, including the Municipal Innovation Fund and the Tax Incentive Program for Innovation. Correspondingly, the local government mapped out a "Route of Innovation", in order to identify and interconnect the city's innovation and technology strategic points as a means to present and promote Florianópolis' innovation ecosystem through a roadmap, extending from the city center to the North of the island. The "Route of Innovation" also aims to connect government, academia, companies, and the community in general, to leverage the entrepreneurial and innovative potential of all actors involved [12].

Recently, two major events have marked Florianópolis, also known as Floripa, development towards a more sustainable city, the new operation of the Florianópolis International Airport and the reopening of the Hercílio Luz Bridge. The Floripa Airport has been managed by a company that also manages Zurich Airport, assuming the city's international airport operations for a period of 30 years and investing in the construction of a new passenger's terminal, inaugurated in 2019. Additionally, the iconic Hercílio Luz Bridge, the longest suspension bridge in Brazil and the first link from Santa Catarina island to the mainland, was restored and reopened to the public on 30 December 2019 after 28 years of closure. 
In this context, a research project named the "Smart Floripa Project" was developed between 2018 and 2019 in order to determine whether or not, and to what extent, the KBUD framework could contribute to transform Florianópolis into a smart city of innovation by 2030. The Smart Floripa Project was promoted as a joint effort of a set of institutions, including the Federal University of Santa Catarina, the Institute of Advanced Studies of the University of São Paulo, the Queensland University of Technology, Fecomércio SC, Senac SC, the Brazilian Association of Software Companies, the Lixo Zero Brasil Institute, the Government of the State of Santa Catarina, and the Municipality of Florianópolis.

The investigation was developed as a qualitative study, with surveys and in-depth interviews with multiple stakeholders engaged in the city's innovation ecosystem. The results, as indicated below, revealed that Florianópolis' potential for innovation stemmed from its natural, human, social, and intellectual characteristics, and the main obstacles opposing the city's ambition to become a smart city of innovation stemmed from significant political and governance gaps [13-15].

These political and governance gaps consist, first, of an alarming lack of experience in evidence-based public policymaking amongst all the city's stakeholders. As a result, decision-making processes do not rely on concrete data or scientific evidence, which, bottom line, leads to poor quality and unsustainable public policies, as both public and private managers lack the knowledge and consistent data on sustainable urban development opportunities and challenges [16]. In other words, the city needs to establish a support model for public policy decision making, which could be provided by the KBUD framework.

Finally, Florianópolis needs to balance its innovative ambition with sustainable urban development standards, especially in regards to social equity and environmental protection. In this case, it must be explored whether or not KBUD can articulate these elements and what the existing benchmarks and references are in the matter. In this setting, this paper aims to collect inputs and reflections for the drafting of evidence-based public policies in favor of Florianópolis' ambition to become a smart city of innovation within sustainable development standards, that is, balancing economic prosperity, social equity, and environmental protection through technology and innovation.

\section{Knowledge-Based Urban Development of Florianópolis}

As mentioned above, KBUD is one of those contemporary terms that has been successfully applied for explaining the overall development of urban locations [17]. The model has gained popularity as it combines four main elements that are considered to be crucial (positive) to development trajectories and pathways [18]. The KBUD framework has become increasingly popular during the last two decades and was conceived in the mid-1990s [19] and has gone through a significant number of updates and detailing in contemporary literature. Because the advance of economies is being radically altered by dynamic processes of economic and territorial restructuring, supported by knowledge and innovation [20-22], the KBUD framework offers a potentially beneficial set of instruments (Figure 1), which can improve the well-being and competitiveness of cities [23,24]. 


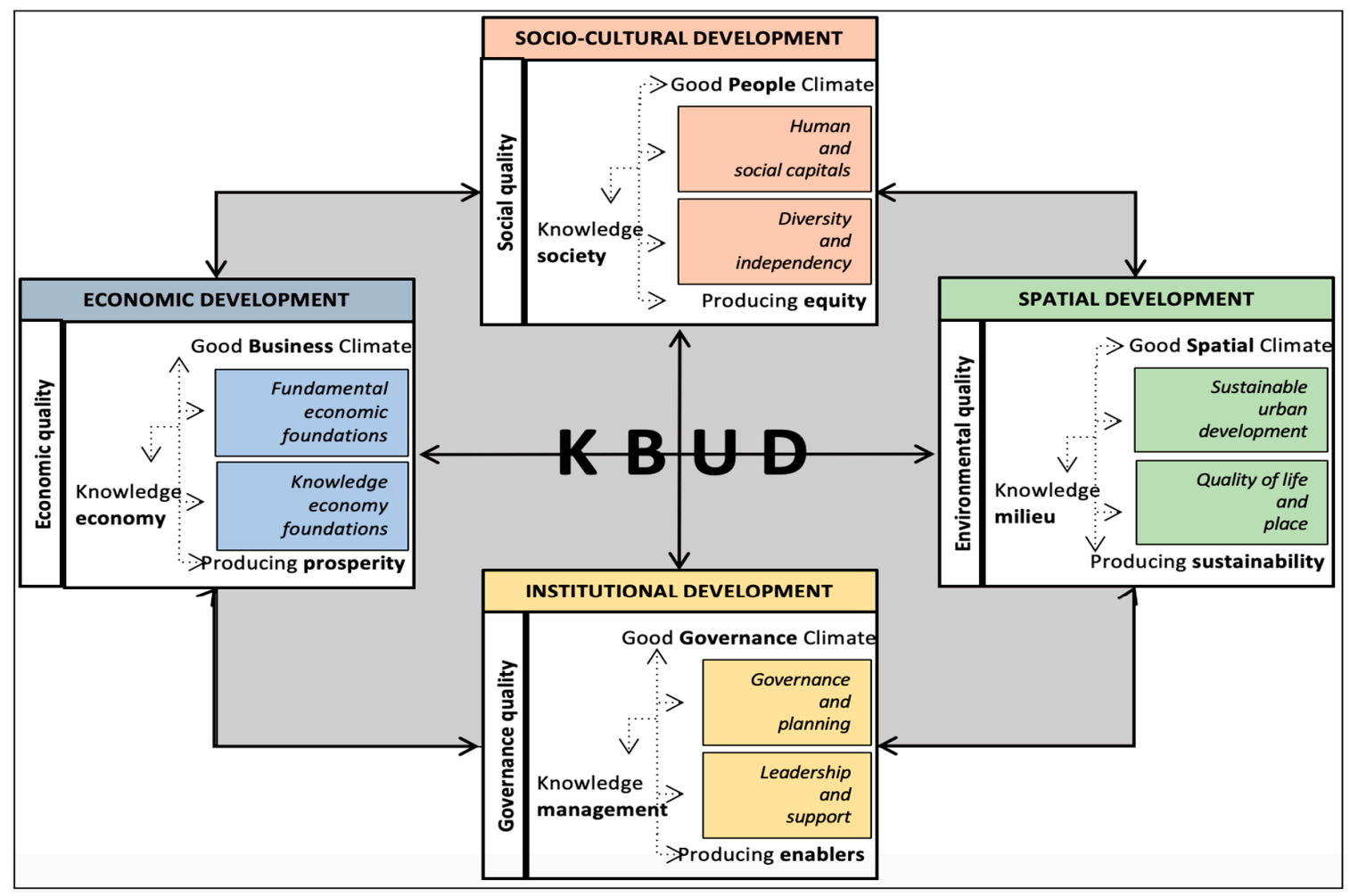

Figure 1. The knowledge-based urban development framework, derived from [18].

Cities (as cases) are interesting study subjects as they are always unique and different in their contextual properties. Locational awareness is fundamental in KBUD [25]. For example, people and organizations tend to follow their local and national cultures in the ways they organize, conduct, and perceive work, leisure, and, particularly, the use of (smart) services as a part of daily living rhythm. Industrial heritage and path-dependency matters as they are intertwined with the social condition of the particular urban contexts under study, Florianópolis being the case here. The growing concentration of technology companies and higher education institutions, associated with KBUD practices, has offered an opportunity to transform Florianópolis into a hub for innovation and knowledge in Brazil [26,27].

Figure 1 outlines the overall structure of the framework and mindset that is important for KBUD. Urban development is considered through four main elements, namely economic, sociocultural, spatial (or environmental), and institutional domains. These four elements provide a tested and well-functioning categorization system for empirical analyses [28]. Under this perspective, the KBUD process in Florianópolis comprises the development of innovation hubs with national relevance and impact, especially in the information technology sector. The development of these innovation districts in the city offers strong potential to produce codified and tacit knowledge, supporting a shift to the knowledge and innovation economy and boosting economic, social, and human gains [29].

The spatial development category, in Figure 1, is the most important one in relation to sustainable and environmentally sound urban development. Whereas the economic approach is considered to be a straightforward assessment of economic performance in time and place, the spatial layer instead stresses the importance of quality of life and clean urban environment as a part of it [30]. There are close connections to the sociocultural dimension of KBUD as an integrative platform for understanding the diversity and complexity of theoretical challenges related to social and environmental structuring of cities [31]. This is supported by an easily verifiable notion that "sustainability" is, nowadays, often connected with urban "smartness", as indicated by Figure 1. One of the early contributions to digitalization and technology-based (smart) urban development was done by Graham and Marvin [32], roughly around the same time when Knight [19] wrote about knowledge-based development concept. Their work pointed out the importance of communication technologies in the evolution of cities. 
After these initial considerations, technological advancements have expanded to include green and environmentally friendly new solutions aiding cities to improve their surroundings, such as in the new ways of improving their surroundings, working locations, and leisure hotspots $[33,34]$.

Finally, institutional aspects are needed in KBUD as the development of smartness and environmental conditions are founded on governance quality. It is commonly acknowledged that governmental operability, well established forms of citizen participation, and transparency in public decision making are fundamental components of KBUD (as well as democracy) [35]. The developments of inclusive smart services are often realized in public-private partnerships and in other forms of collaborative arrangements. Advancements in planning theory (e.g., actor networks) provide a decisive intellectual capacity for KBUD when applied in case studies. Overall, the KBUD framework provides insight into the highly complex phenomena of urban evolution that requires an understanding of the time-space trajectories in relation to progression in the field of smart technologies and decline of environmental conditions [16].

\section{Methodology}

The methodological approach consisted of a set of qualitative analysis methods. Firstly, an online survey was conducted to capture the perspectives of experts from the State of Santa Catarina on KBUD and innovation performances of Florianópolis. Secondly, in-depth face-to-face interviews were undertaken with key policymakers of the State of Santa Catarina to evaluate the survey findings and gather additional insights into Florianópolis' innovation ecosystem and asset base.

\subsection{Online Survey}

In order to structure the online survey questionnaire, some indicators of the 2018 Global Innovation Index were selected in order to measure Florianópolis' performance. The Global Innovation Index aims to capture the multidimensional facets of innovation by providing a rich database of detailed metrics for 126 national economies, which represent $90.8 \%$ of the world's population and $96.3 \%$ of the global gross domestic product (GDP). A wide range of high-, medium-, and low-income countries use the index as a tool for understanding, benchmarking, and improving their innovation performances [36]. Taking advantage of the Global Innovation Index framework, a questionnaire was set up for experts from the State of Santa Catarina to evaluate the performance of Florianópolis in relation to Brazil's ranking, according to main indicators clustered under three categories, as presented in Table 1.

Table 1. Global Innovation Index indicators used in the design of the questionnaire (source, authors).

\begin{tabular}{ccc}
\hline Innovation Input Performance & Innovation Output Performance & Innovation Overall Performance \\
\hline Institutions & Outputs of knowledge and technology & Strengths \\
Human capital and research & Creative outputs & Weaknesses \\
Infrastructure & & Opportunities \\
Market sophistication & Threats \\
Business sophistication & & Overall performance \\
\hline
\end{tabular}

The questionnaire also used Brazil's assessment in comparison with the Organization for Economic Co-operation and Development (OECD) and Latin American countries as guiding benchmarks. The respondents were asked to rate Florianópolis' innovation performance considering the national performance, defining it using a 7-scale Likert system. For each category, respondents were also asked to state the main reasons for their rating, as well as what could be done to improve the performance in that specific area.

The first version of the questionnaire included a total of 55 questions, 22 questions sought quantitative responses and the remaining 33 questions sought qualitative responses. A pilot version of the questionnaire was placed into a Google Form and sent to 10 people. After considering the feedback received, the questionnaire was shortened to 35 questions, 22 of them quantitative and 13 qualitative. 
The final version of the questionnaire was sent by e-mail to 100 selected experts, i.e., innovation and knowledge-based development specialists belonging to the following four sectors: public, private, academic, and not-for-profit. The survey was left open for 15 days and a strong follow-up was made by phone and WhatsApp to receive as many responses as possible. In total, 55 valid responses were received ( $55 \%$ response rate). Among these respondents, 17 respondents were from the not-for-profit sector, 16 respondents were from the private sector, 10 respondents were from public sector, and 12 respondents were from the academic sector.

Quantitative responses were analyzed with the google forms' graphic generation tools, whereas the analysis of the open-ended questions was made by a coding system, based on KBUD dimensions. A total of 16 codes were identified, 4 for each dimension (economic development, sociocultural development, spatial development, and institutional development), and highlighted with a different color (Table 2). Each open-ended response was also coded considering the subcodes for each code category. In total, 660 responses were read, coded, and subcoded, accordingly. Additionally, the main issues from the responses were manually identified and added to a strengths, weaknesses, opportunities, and threats (SWOT) table for further analysis.

Table 2. The coding system (source, authors).

\begin{tabular}{|c|c|c|}
\hline No & Code & Subcode \\
\hline \multicolumn{3}{|r|}{ Economic development dimension } \\
\hline 1 & Business context & $\begin{array}{l}\text { ICT companies; international; companies; large companies start-ups; } \\
\text { business model; business culture; industry of services }\end{array}$ \\
\hline 2 & Innovation activity & $\begin{array}{l}\text { United ecosystem; engaged actors; innovative businesses; entrepreneurship } \\
\text { environment; creative companies; business organization; entrepreneurial } \\
\text { culture; innovation events; market size; programs for start-ups; competitive } \\
\text { market; innovation cluster; innovation culture }\end{array}$ \\
\hline 3 & Business infrastructure & $\begin{array}{l}\text { Laboratories; investment in infrastructure; technological park; innovation } \\
\text { centers; living labs; research centers; infrastructure planning; technology; } \\
\text { education centers }\end{array}$ \\
\hline 4 & Investment & $\begin{array}{l}\text { Funds; credit; support for economic development; foreign direct investment } \\
\text { support for the entrepreneur; investment in R\&D; companies' attraction; } \\
\text { finance mechanism; venture capital }\end{array}$ \\
\hline \multicolumn{3}{|c|}{ Sociocultural development dimension } \\
\hline 5 & Labor force & Talented people; knowledge workers; human capital; talents attraction \\
\hline 6 & Education institutes & $\begin{array}{l}\text { university prestige; university ranking; university role; innovative } \\
\text { academy; academy corporatism; ideological bias of university }\end{array}$ \\
\hline 7 & Skill sets & $\begin{array}{l}\text { Education investment; education quality; technical courses; English } \\
\text { language knowledge; training programs; specialization; knowledge } \\
\text { absorption; knowledge transformation; knowledge exchange; knowledge } \\
\text { application; academia curriculum; intellectual property; incentives in } \\
\text { schools and universities to discover talents; applied research; knowledge } \\
\text { sharing }\end{array}$ \\
\hline 8 & Cultural assets & $\begin{array}{l}\text { Local culture; tolerance; city branding; provincialism; city profile; } \\
\text { receptivity }\end{array}$ \\
\hline \multicolumn{3}{|r|}{ Spatial development dimension } \\
\hline 9 & Locational characteristics & $\begin{array}{l}\text { Geographically isolated; island limitations (no industries); space for } \\
\text { companies; non-industrial area }\end{array}$ \\
\hline 10 & Quality of life and place & Living cost; security \\
\hline 11 & Spatial infrastructure & $\begin{array}{l}\text { Urban mobility; airport; housing; distance from airport to innovation } \\
\text { clusters; sanitation }\end{array}$ \\
\hline 12 & Sustainability & $\begin{array}{l}\text { Investments in sustainable infrastructure; environmental impact; nature; } \\
\text { preservation areas; energy (replace use of fossil fuel); conscious } \\
\text { development; environmental and sustainable technologies }\end{array}$ \\
\hline
\end{tabular}


Table 2. Cont.

\begin{tabular}{|c|c|c|}
\hline No & Code & Subcode \\
\hline \multicolumn{3}{|r|}{ Institutional development dimension } \\
\hline & & Government effectiveness; political continuity; political stability \\
\hline 13 & Governance characteristics & $\begin{array}{l}\text { Public agencies; organs effectiveness; ICTs/online government; } \\
\text { accountability; political environment (provincial); political articulation }\end{array}$ \\
\hline 14 & $\begin{array}{l}\text { Institutions, partnerships, } \\
\text { and international relations }\end{array}$ & $\begin{array}{l}\text { Quadruple-helix partnerships; public-private partnerships; } \\
\text { university-company partnership; integration between different sectors; } \\
\text { networking; cooperation; integration with the international environment; } \\
\text { international exchange; international publications; exchange programs; } \\
\text { foreign students and researchers; partnership with international entities; } \\
\text { invest in high tech international events; internationalized market; } \\
\text { international positioning }\end{array}$ \\
\hline 15 & Support mechanisms & $\begin{array}{l}\text { Institutional arrangement; strong entities, e.g., ACATE, Business hub, } \\
\text { CERTI; Associationism; active leadership; service to entrepreneurship; } \\
\text { governmental incentives, Fapesc; public; investment/incentives; tax } \\
\text { incentive programs }\end{array}$ \\
\hline 16 & Regulatory environment & $\begin{array}{l}\text { Municipal Law of Innovation; legislation; bureaucracy; public policies; high } \\
\text { cost of production; patent applications; legal security }\end{array}$ \\
\hline
\end{tabular}

\subsection{Face-to-Face Interviews}

To gain an in-depth understanding of Florianópolis' innovation performance and potentials, the survey results were further explored and validated through in-depth interviews with 12 key policymakers and policy influencers of the State of Santa Catarina. Due to the importance of the quadruple helix for innovation ecosystems, the interviewees were selected at the ratio of 3 representatives of each sector: public, private, academic, and non-for-profit, as shown in Table 3. Seniority and high-level innovation knowledge were also factors considered for the interviewee's selection.

Table 3. Sectoral and institutional representation of the interviewees (source, authors).

\begin{tabular}{|c|c|c|c|}
\hline Public Sector & Academic Sector & Not-For-Profit Sector & Private Sector \\
\hline $\begin{array}{l}\text { Federal Ministry of Science, } \\
\text { Technology, Innovation, } \\
\text { and Communications } \\
\text { State Government } \\
\text { Florianópolis Metropolitan } \\
\text { Area Authority } \\
\text { Municipal Technology and } \\
\text { Innovation Authority }\end{array}$ & $\begin{array}{l}\text { Federal Institute of Santa } \\
\text { Catarina, Department of } \\
\text { Innovation } \\
\text { Federal University of Santa } \\
\text { Catarina, Research \& } \\
\text { Innovation Hospital } \\
\text { Federal University of Santa } \\
\text { Catarina, Administration }\end{array}$ & $\begin{array}{l}\text { National Technology \& } \\
\text { Innovation Center } \\
\text { Santa Catarina Sate } \\
\text { Industry Federation }\end{array}$ & $\begin{array}{l}\text { Tech Solution Company } \\
\text { with Applications on Smart City } \\
\text { Communications } \\
\text { Tech Solution Company with } \\
\text { Applications on Financial and } \\
\text { Commercial Transactions }\end{array}$ \\
\hline
\end{tabular}

The semi-structured interviews gathered an average of nine recording hours. Interviewees were asked to sign a consent and confidentiality agreement to participate in the research. After giving interviewees a brief introduction on the investigation and the online survey results, the researchers directed the following six key conversation starter questions, adding complementary questions whenever necessary:

- What are the main challenges and opportunities in the development of Florianópolis as a smart innovation island?

- What roles have the academic, public, not-for-profit, and private sectors been playing in Florianópolis development as a smart innovation island?

- How can Florianópolis perform well in promoting, attracting and talent retention, and investments to achieve its goal of becoming a smart innovation island?

- What is your vision of Florianópolis to become a smart innovation island?

- What actions can be taken to support Florianópolis' vision to become a thriving smart innovation island?

- Do you have any other comments or perspectives to add on? 
Each transcribed interview text was carefully read and analyzed to identify each interviewee's perspectives on the opportunities and challenges for Florianópolis's transition towards becoming a smart city of innovation considering all four KBUD dimensions.

\section{Results}

\subsection{Survey Results}

As previously mentioned, the online expert survey targeted to evaluate the performance of Florianópolis in relation to Brazil's ranking in the 2018 Global Innovation Index, in which Brazil ranked 64th (out of a total of 126 countries). In comparison with the OECD and Latin American countries, Brazil was respectively ranked in the 37 th and sixth position.

The respondents rated Florianópolis' innovation performance considering the national performance, defining it on a seven-scale Likert system as follows: 1 (far below), 2 (moderately below), 3 (slightly below), 4 (at national average), 5 (slightly above), 6 (moderately above), and 7 (far above). For each category, respondents were also asked to state the main reasons for their rating, as well as what could be done to improve the performance in that specific area.

The questionnaire was sent by e-mail to 100 eminent innovation specialists, of which 55 provided responses. Overall, $83 \%$ of the respondents rated Florianópolis' innovation performance as better than Brazil's performance, among which, $26 \%$ considered it slightly above, $35 \%$ moderately above, and $22 \%$ far above. Respondents also evaluated Florianópolis performance as superior to the national performance in all innovation input and output areas, as shown in Tables 4 and 5 below.

Table 4. Respondent views on the specific innovation input performance areas of Florianópolis (source, authors).

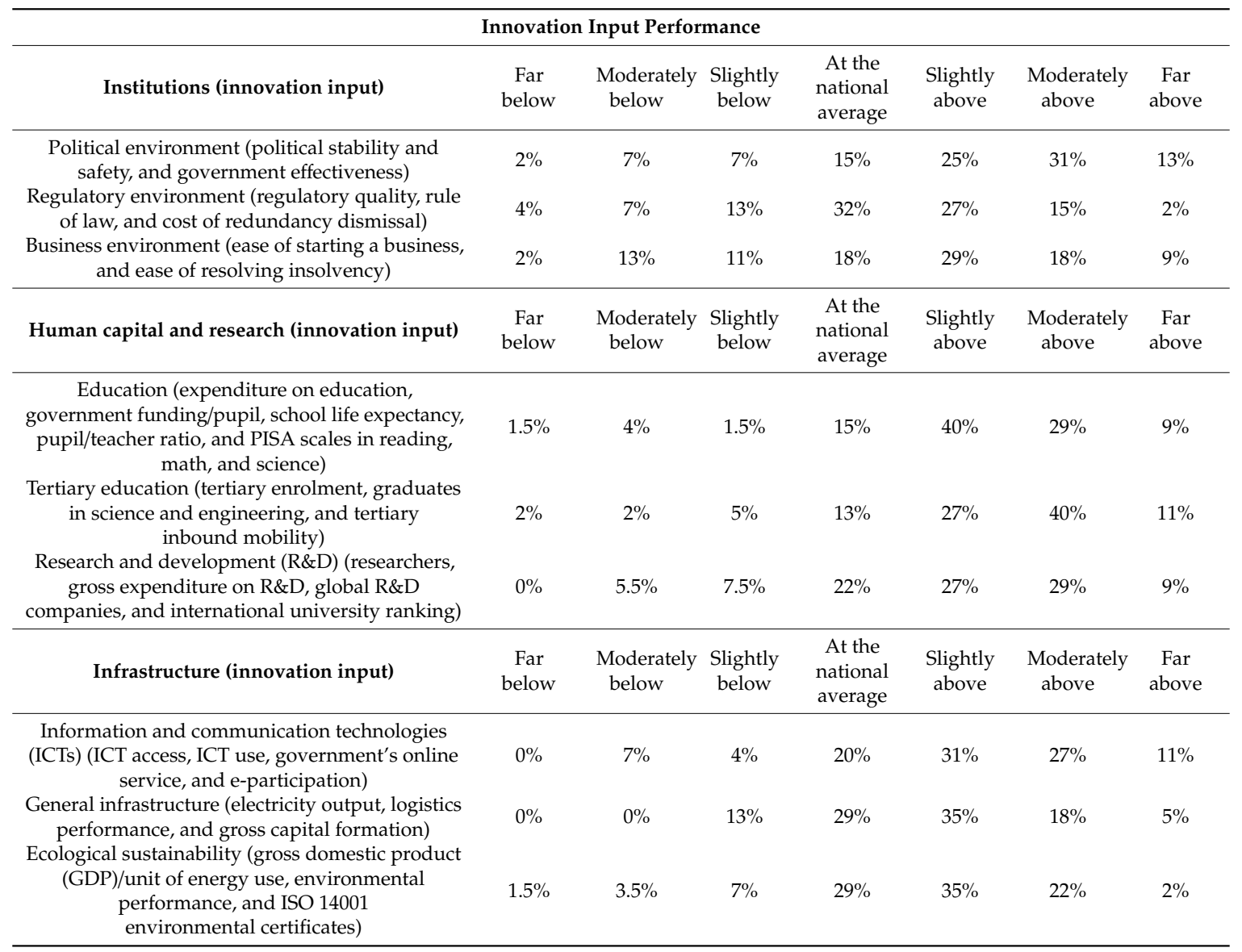


Table 4. Cont.

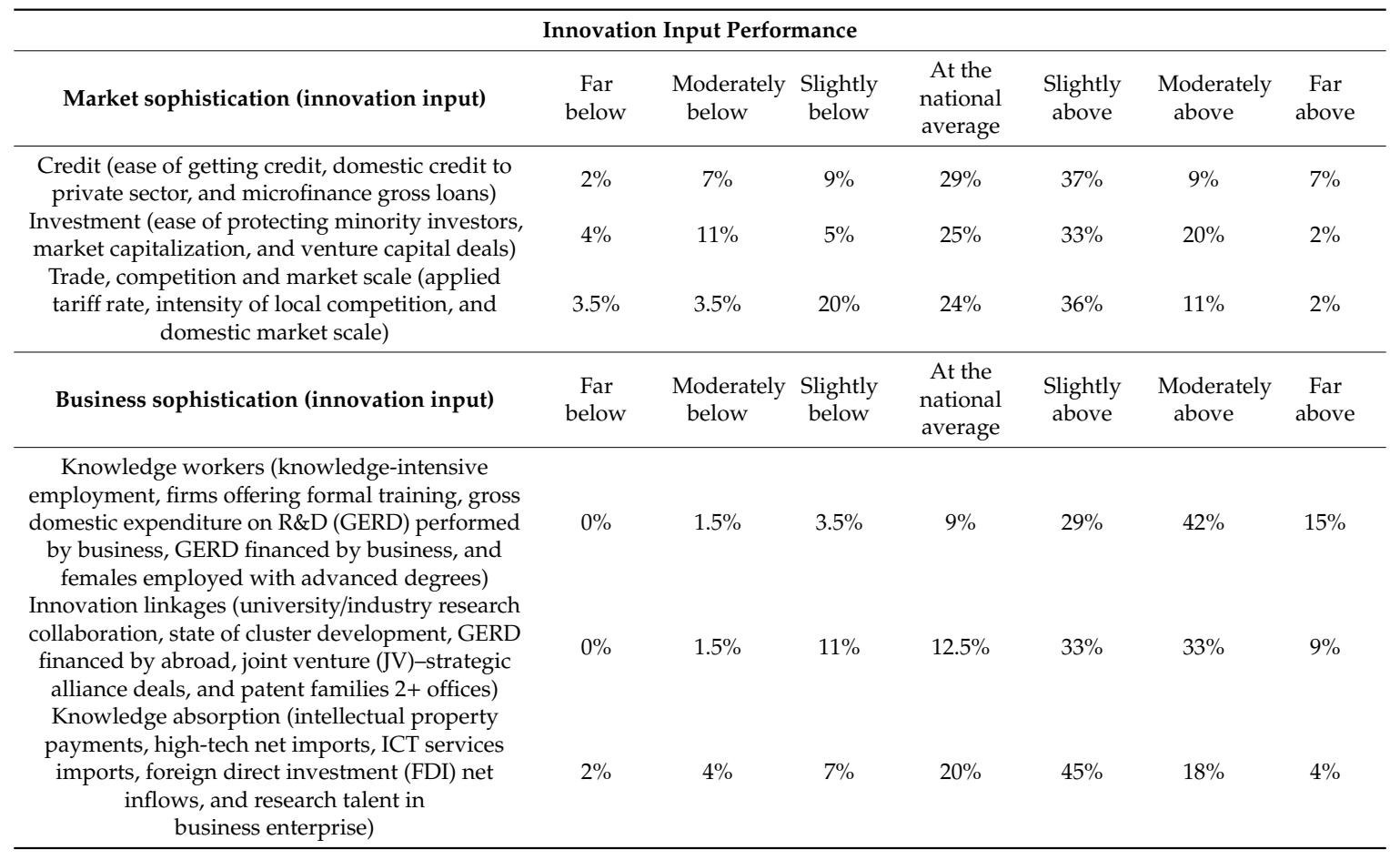

Table 5. Respondent views on the specific innovation output performance areas of Florianópolis (source, authors).

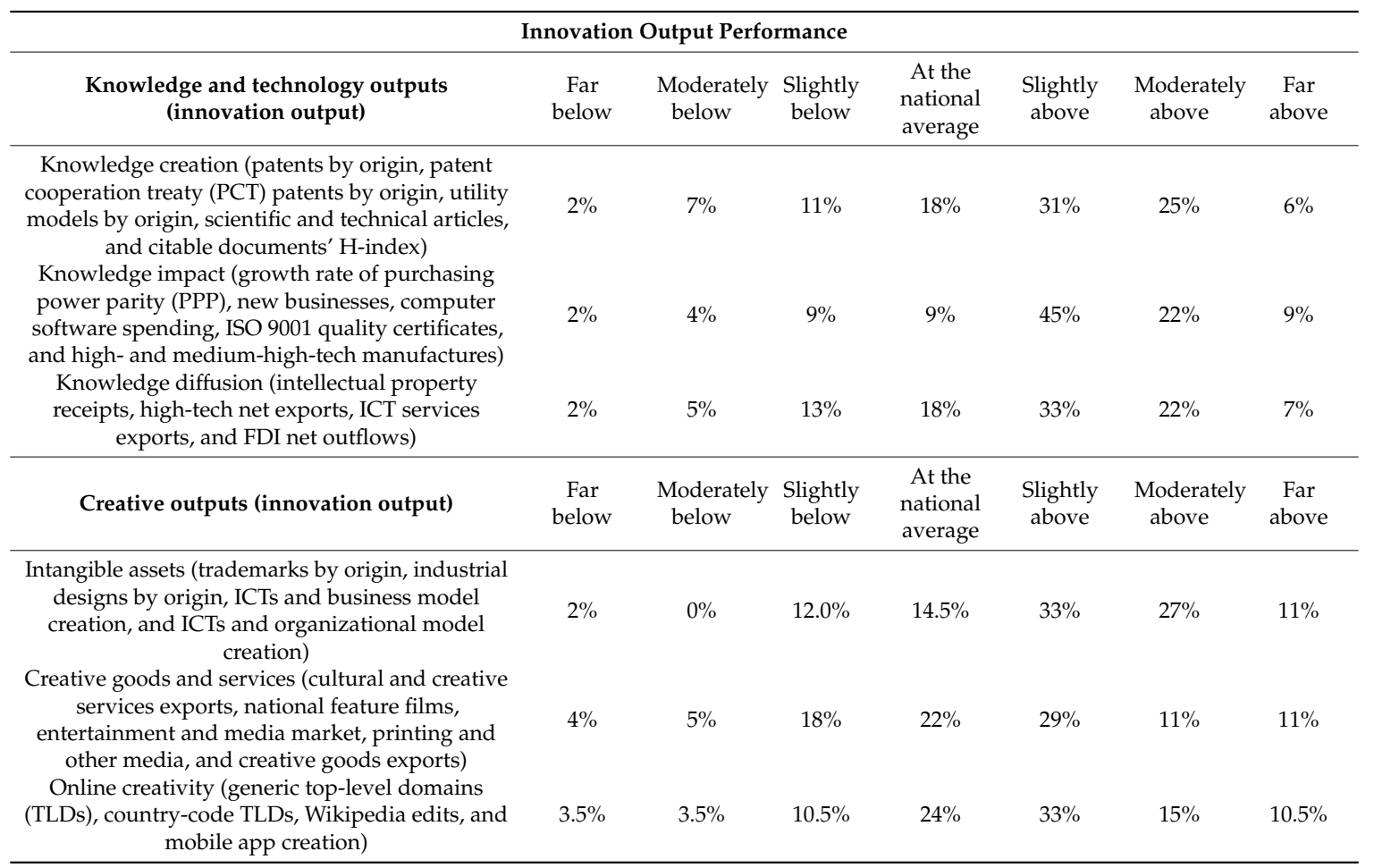

In order to further deepen the assessments and better understand the provided scores, respondents were asked to justify their answers, by indicating what could be done to improve the city's performance with respect to each indicator and by naming three main strengths, weaknesses, opportunities, and threat areas related to Florianópolis' overall innovation performance. The answers to these 
open-ended questions were analyzed according to a manually created code list based on the four main dimensions of the KBUD framework, as shown in Table 6 below.

Table 6. Content analysis codes by knowledge-based urban development dimensions (source, authors).

\begin{tabular}{|c|c|c|c|}
\hline Sociocultural Development & Spatial Development & Institutional Development & Economic Development \\
\hline Labor force & Locational characteristics & Governance characteristics & Business context \\
\hline Educational institutes & Quality of life and place & $\begin{array}{l}\text { Institutions, partnerships, } \\
\text { and international relations }\end{array}$ & Innovation activities \\
\hline $\begin{array}{c}\text { Skillsets } \\
\text { Cultural assets }\end{array}$ & $\begin{array}{l}\text { Spatial infrastructure } \\
\text { Sustainability }\end{array}$ & $\begin{array}{l}\text { Support mechanisms } \\
\text { Regulatory environment }\end{array}$ & $\begin{array}{l}\text { Business infrastructure } \\
\text { Investment }\end{array}$ \\
\hline
\end{tabular}

In the economic development dimension of KBUD, the following four main areas were identified: business context, innovation activities, business infrastructure, and investment. Innovation activity was the subdimension most cited by respondents, with $36.5 \%$ of total mentions, $70.12 \%$ of them being positive comments. This can be explained by Florianópolis actors' engagement and the ability to act with a cluster approach (named locally as associationism), which has put together a well-structured innovation ecosystem. According to one of the respondents, "Florianópolis is a point off the curve in relation to Brazil. I see a very great leadership, especially from ACATE, in the organization and dynamization of technology companies. The opportunities that are presented by ACATE to business owners, partners or not, are varied and current". Respondents also stated that the possible improvements in this area need to focus on monitoring, evaluating, and consolidating present actions in order to foster and improve prospective innovation development.

As per the business context, it became evident that despite the recognition of expressive information and communication technology (ICT) companies' activities in the city, there was room for improvement. More than $19 \%$ of citations were about improvement and 30.23\% referred negatively to this area. Respondents considered the market to be "very small", mostly represented by small to medium size enterprises (SMEs) with little intention or expression on exports and a reduced call to increase productivity.

The innovation business infrastructure has been quite well developed in Florianópolis. It comprises innovation districts, innovation centers, recognized incubators, and accredited laboratories (e.g., Embrapii). However, there is a demand for better and modern technologies, such as a comprehensive optical fiber network, and low carbon infrastructure, as well as social innovation experiment environments like the living labs. About $30 \%$ of the comments on the business infrastructure were positive, $35 \%$ were negative, and $35 \%$ were neutral or progressive, but still pointed out the need for improvements.

Public or private sector investment was perceived as a major demand, i.e., $47.61 \%$ of citations highlighted the necessity of immediate improvements, and 37.3\% referred negatively to investment availability and opportunities. "Sinapse da inovação" or "The Synapse of Innovation", an incentive program for innovative entrepreneurship that offers financial resources, training, and support to transform innovative ideas into successful enterprises, was cited as one of the leading instruments developed by the market. Despite a few business angels and investment banking, the general perception was that the investment capacity was limited and precarious. One of the respondents highlighted that "it is necessary to create a culture of private investment in areas such as culture and tourism, which still rely heavily on public investment". Respondents also pointed out a lack of investment in R\&D and little support for entrepreneurs and venture capitalists.

The sociocultural development dimension encompasses the following four subdimensions: labor force, educational institutes, skill sets, and cultural assets. Labor force, with $46 \%$ of positive references, is a major asset of the city, which attracts talented and creative people [37]. Nevertheless, as the innovation sector is growing, it is also a concern about $31 \%$ of the mentions on that topic were negative, $23 \%$ of them highlighted specifically the need for improvements. One respondent stated that "the city must attract even more knowledge workers, including foreign researchers, and maintain the 
ones that are already working in it". Another respondent also pointed out that "educational institutions must contribute to the creation and diffusion of knowledge, as well as in the training of knowledge workers in new areas of digital transformation". Additionally, three other commonly mentioned concerns regarding the labor force were the following: the lack of entrepreneur women, innovators not being high-tech businesses, and the need for continuous qualification of the existing workforce.

Because Florianópolis has strong educational institutes, $75 \%$ of the expert comments on the education system were positive. Federal University of Santa Catarina (UFSC) is recognized as one of the best in Brazil, especially its engineering courses; also, the State University (UDESC), and other metropolitan universities, are committed to innovation and have contributed to the development of the innovation ecosystem by supplying talent. Appointed possibilities of improvement included a greater diffusion of the knowledge generated in universities and better collaboration between the academic and private sectors, to transform scientific knowledge into innovation.

Half of the respondents highlighted education and skill sets as key pillars for improvement in all aspects related to innovation. In this sense, despite the good universities, respondents drew special attention to the need to invest in basic education, technical training programs, knowledge diffusion and application. One of the experts remarked that "innovation should be treated and stimulated in basic education, and academia research should meet the demands and needs of the society and industry", which would require, according to another respondent, "the revision of the education policies, educational methodologies, and lecturer' qualifications".

On the one hand, the main cultural assets highlighted by the respondents were the culture of innovation, city branding, local culture, and receptivity of the city. On the other hand, provincialism, the fact that creativity is not seriously taken as a business, and egocentrism were indicated as prejudicial elements to the innovation ecosystem. According to the respondents, Florianópolis needed to open itself to the world, show what has been done, and timely consolidate itself as a technology and innovation pole. Comments on this subdimension were balanced, i.e., $30 \%$ of them were positive, $35 \%$ were negative, and about $35 \%$ were pointing to the need for consolidation.

Regarding the spatial development dimension, the most cited themes were locational characteristics, quality of life and place, spatial infrastructure, and sustainability.

In relation to the locational characteristics, although the island's natural beauty was acknowledged as an important magnet to the creative class, the concurrent land use limitations, and high prices, as well as the impediment of industrial activities were appointed as negative factors. The experts highlighted concerns with sanitary and energy issues, as well as the physical distance between Florianópolis and other important national innovation hubs such as São Paulo. As a result, most of the comments, around $60 \%$, on locational characteristics were negative.

Quality of life and place was cited mainly as a positive contributor to the city's success (45.45\%), but respondents expressed some concern about its decline in recent years. High cost of living, lower wages, and public safety issues were pointed out as sensitive areas to boost the permanence of the creative class, entrepreneurs, and skilled labor force. Most of the respondents, however, believed that Florianópolis should be positioned as "by far the best city to live in Brazil".

Spatial infrastructure was the most cited subject in the spatial dimension, with $68.51 \%$ of negative comments, mostly due to the city's grave mobility issues. Among the suggested improvements, the most critical ones were the following: investments in a better road system, multimodal public transportation, and the creation of new urban centralities with housing options accessible to various levels of income (to reduce the need to move from home to work). The distance between the airport and the innovation clusters, as well as the lack of technological structure to support new technologies, were also indicated as important concerns. As one of the respondents highlighted, "Florianópolis' transportation and sanitation are far behind from some Brazilian states, which ultimately undermines corporate productivity and ecological sustainability in a more general way".

Sustainability was also highlighted as a significant concern by $48.27 \%$ of the respondents. Citations indicated a desire for more public investments in sustainable infrastructure, renewable energy sources, 
environmental and sustainable technologies, environment preservation areas, as well as the need for greater compliance with housing, land use, and environmental regulations. Some respondents also suggested that "specific programs related to the UN Sustainable Development Goals should be developed".

Lastly, the institutional dimension was pointed out as the most challenging area in the city. The lack of ideal governance characteristics; institutions, partnerships, and international relations; support mechanisms; and regulatory environment were cited by almost all respondents. Most of the citations (54.56\%) mentioned the necessity to improve governance standards and practice, and $36.75 \%$ of them were extremely critical of the current governance system.

The main concerns regarding governance characteristics revolved around the non-continuity of political actions, the ineffectiveness of public agencies, the lack of accountability, and inadequate management of innovation. "The state and municipal government has adopted much more rhetoric of valuing innovation than concrete actions coordinated with private agents", argued one of the respondents. Possible improvements could be obtained, according to the respondents, through greater agility and dynamic management of public entities, policy transparency and open data, long-term and community-driven policies, governmental will, interest and openness to innovation, well-conducted and communicated policy evaluations, and e-participation.

Institutions, partnerships, and international relations were pointed out as the governance subdimension of greater importance to innovation development in the city. Respondents emphasized the importance of quadruple-helix partnerships, even though criticizing them for their usual inertia and impracticality. Respondents highlighted the necessity to strengthen public-private partnerships and technical-scientific cooperation agreements between the university and productive sectors. Other cited issues were the need for greater city internationalization to build an adequate environment for international business, through international exchange programs, networking, international missions, and international cooperation programs.

Experts praised the city's associationism and active leadership, consistent with the several innovation support mechanisms developed through the years, such as incubators, institutional arrangements, innovation entities (ACATE, CERTI, and business hubs) and some tax incentives. Nonetheless, respondents pointed out that Florianópolis needs to offer significant tax incentives, benefits, and facilities to attract knowledge-intensive companies and to support even more the already existing creative and innovative industry. As one of the respondents observed, "there is no strong micro-credit financing policy. This year the Municipality of Florianópolis launched zero interest financing for small business owners, but there is a lack of stronger government action".

Finally, the regulatory environment was heavily criticized and pointed out as the sector that, if refined, could boost the development of Florianópolis as a smart innovation island. Even though the Florianópolis Municipal Law of Innovation was referred to as a good starting point, the need for de-bureaucracy was mentioned by many experts, as well as the need to improve legal certainty, to facilitate business implementation, to ease patent registration, to have more flexible and agile regulatory bodies, and to define specific public policies to stimulate the innovative sector.

\subsection{Interview Results}

This section reports the results of the interviews with key policymakers and policy influencers, selected amongst actors belonging to each of the four sectors, i.e., public, not-for-profit, private, and academic (see Table 7 below). 
Table 7. Interviewee profiles (source, authors).

\begin{tabular}{cll}
\hline Category & \multicolumn{1}{c}{ No } & \multicolumn{1}{c}{ Expertise and Relevance } \\
\hline \multirow{3}{*}{ Public sector } & Interviewee \#1 & $\begin{array}{l}\text { Federal Ministry of Science, Technology, Innovation, and } \\
\text { Communications }\end{array}$ \\
& Interviewee \#2 & $\begin{array}{l}\text { State Government Florianópolis Metropolitan Area Authority } \\
\text { Municipal Technology and Innovation Authority }\end{array}$ \\
& Interviewee \#3 & $\begin{array}{l}\text { Technology Solution Company with Applications on Smart } \\
\text { City Communications }\end{array}$ \\
& Interviewee \#4 & Technology Solution Company with Applications on Financial \\
& and Commercial Transactions \\
Private sector & Interviewee \#5 & Real Estate development group \\
& Interviewee \#6 & National Sustainable Waste Organization Institute \\
& Interviewee \#7 & National Technology and Innovation Centre \\
Not-for-profit sector & Interviewee \#8 & Santa Catarina State Industry Federation \\
& Interviewee \#9 & Federal Institute of Santa Catarina, Department of Innovation \\
& Interviewee \#10 & Federal University of Santa Catarina, Research \& Innovation \\
Academic sector & Interviewee \#11 & Hospital \\
& Interviewee \#12 & Federal University of Santa Catarina, Administration \\
\hline
\end{tabular}

In total, 12 key policymakers and policy influencers of Florianópolis participated in the interviews. As an evidence of lack of diversity in gender and race in leadership positions in Florianópolis, all interviewees were white male in every sector.

Each interview was carefully transcribed and analyzed to identify each interviewee perspective on the opportunities and challenges for Florianópolis' transition towards becoming a smart city of innovation. The relevant citations were grouped per KBUD dimension, i.e., institutional, environmental, sociocultural, and economic, as well as per helix, i.e., public (GOV), private (COM), academic (EDU), and non-for-profit $(\mathrm{ORG})$, allowing for the identification of the main challenges and opportunities appointed by each one of the four helixes, in each KBUD dimension and respective codes, as explained below.

Firstly, it is important to highlight that the most cited KBUD dimension was the sociocultural dimension, with 46 references (31.5\%); economic development came in second place, with 39 citations $(26 \%)$, closely followed by the institutional dimension, with 37 citations $(26.7 \%)$. The spatial dimension came in fourth place, with 23 citations (15.8\%).

Regarding the institutional dimension, the most cited code was "institutions, partnerships, and international relations", with 14 citations, followed by governance characteristics and regulatory environment, with nine citations each, and support mechanisms, with five citations. The distribution per helix (KBUD domain) is indicated in Figure 2 below.

As per the code, institutions, partnerships, and international relations, the private and academic sectors perceived, respectively, opportunities for associations and an innovation environment for promoting quadruple helix interactions. The public sector is aligned in the sense of developing public and private partnerships and looks forward to replicating the actual network model in other areas, as well as attracting foreign investors to boost this aspect.

Despite private sector's optimism towards private initiative to collaborate, it also senses the quadruple-helix trust development process as a challenge, which has an echo in the academy's understanding of "islands of innovation within the federal university". The private sector sees the barrier to big companies as a challenge too and the academic sector recognizes "politics" as the reason that prevents innovation from taking off and reaching country and global levels. The not-for-profit sector poses that, despite the lack of direction and market access, the ecosystem allows things to happen. 


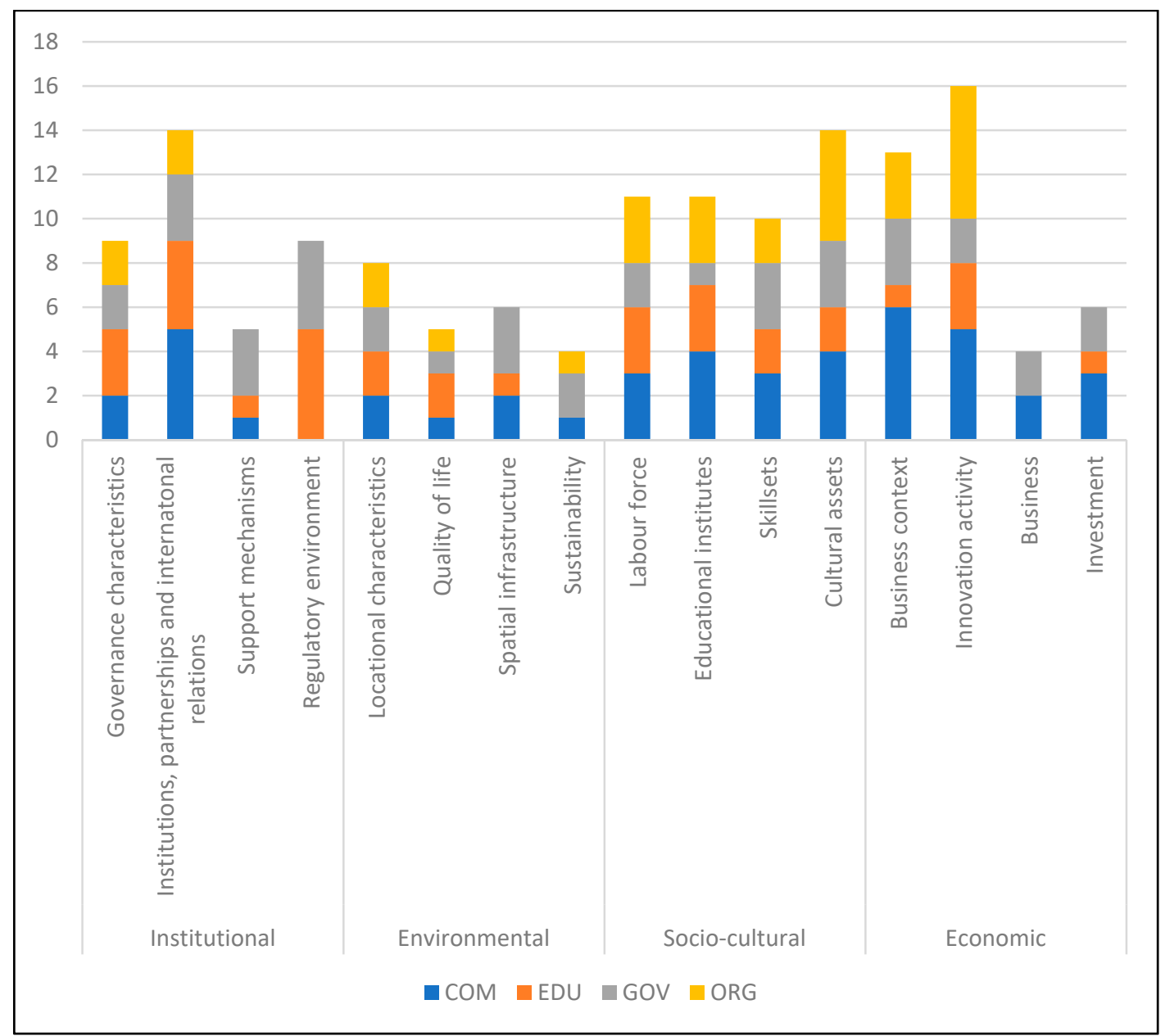

Figure 2. Key topic reference frequency per helix (source, authors).

Governance characteristics are basically seen as a challenge and mostly appointed to the public sector, which is the only helix that perceives opportunities for major players' interactions. The private sector sees governance with a lack of entrepreneurial mindset and is not innovative. One of the interviewees points out that "there is a lack of understanding and perception of the public servers about this new world, the new demands of people and cities. They must know more about Item Response Theory and how to use a database. This way they will not be so immediate and would choose better ways of transport for the city, for example". The academic sector understands the state as a burden, i.e., claims for fewer hindrances and stresses on policy and idea discontinuity. The not-for-profit sector identifies lack of investment in technology and city management.

Regulatory environment was mainly brought up by the academic and public sectors due to the innovation municipal fund, which has raised over R 1 million (approximately USD 185,500) in three projects, evidencing some government involvement towards innovation. As a challenge, both sectors also mentioned the need for de-bureaucratization. Support mechanisms are cited as challenges for both private and public sectors. The academic sector states the lack of local support mechanisms that push companies to develop projects in the northeast region of Brazil, where financial contribution is cut by half. The public sector claims the lack of national and state level development policies in this matter.

The academic sector perceives associations (ACATE) and the innovation park (Sapiens park) as support mechanisms, and the public sector believes that university and private institutes' partnerships should thrive as an opportunity to develop mechanisms for innovation development. 
The spatial dimension was the least KBUD dimension cited by the interviewees, with a total of 23 references. Locational characteristics had eight references; quality of life had five references; spatial infrastructure had six references, and sustainability only had four references.

All sectors highlighted the city's locational characteristics, i.e., its natural beauty, attractiveness, pleasantness, and singularity, as an opportunity for development. Nevertheless, all of them also identified challenges linked to the same locational characteristics, due to its geographical limitations and national and local issues pertaining to those limitations. "Floripa has a movement that is contrary to building things. It is a city with a very preservationist concern, also for being an incredibly beautiful environment, and it's difficult and delicate to be able to make any construction in this context", mentions one of the interviewees.

To the public and not-for-profit sectors, a good quality of life and a high-quality police force are opportunities to develop, whereas the private sector highlighted growing concerns with public security. To the academic sector, the city tends to its disorderly growth and must invest heavily in infrastructure.

Spatial infrastructure, particularly, was appointed by all sectors as a challenging issue, with deficiencies in basic infrastructure, green leisure areas, and urban planning. "Even though there are many beaches here, I almost do not go to the beaches because it is a complete chaos, there are no bars, there is nothing, no innovation. And when it rains, everyone goes to the mall, there is no other thing to do. The few theaters and museums lack equipment. We don't have many parks, green leisure areas", points out one of the interviewees. The private sector highlighted that the city, despite being a tourist destination, lacked enough marinas. The academic and the public sectors both remarked that the city must solve its pressing mobility issues, investing in public transport and urban mobility improvements to better organize the flow of people, goods, and services in the city. An interviewee highlights that "we need actions to improve the day to day of the population. It's hard to keep creative people here with no mobility, taking more than one hour to go to the continent area and come back. Besides being good professionals, they want to have a good quality of life".

Sustainability was the least mentioned aspect. The private sector envisages the city's many environmentally protected areas as an asset to tourism, whereas the not-for-profit sector, with a broader point of view, draws special attention to the city's unique balance between social and economic development and environmental preservation as an opportunity for growth. In terms of challenges, the public sector highlighted the difficult coexistence between urban development and environmental protection, as well as the need to expand the use of geoprocessing tools in the city. One of the interviewees mentions that "Florianópolis has a series of associated difficulties to the space that can be used on the island. Many of our rules, regulations, laws and requirements, have difficulty in coexisting with the environment that needs to be preserved, the progress in a sustainable way and initiatives to restructure the city".

The sociocultural dimension was the most cited KBUD dimension, with 46 references in total. Within its codes, cultural assets were the most mentioned $(n=14)$, followed by labor force $(n=11)$, educational institutes $(n=11)$, and skillsets $(n=10)$. The distribution of references per code and helix is demonstrated in Figure 2.

Cultural assets are foreseen as opportunities by the not-for-profit sector due to a sense of harmony and mutual understanding. The academic sector perceives having a European entrepreneurial influence as an opportunity, and that local culture adaptation to technology is a challenge. Overall, cultural assets are marked by challenges despite the ecosystem's "contagious innovation culture". The private sector points to a lack of leadership, motivation, and willingness; adding to a lack of alignment and diversity by the public sector; and a lack of education and prioritization for the common good by the not-for-profit sector.

Labor force analysis is quite intertwined with the code skill sets. It is generally perceived both as a key and bottleneck aspect by the quadruple helix. Private and academic sectors highlight capacity building and the need for continuous training as the main challenges, whereas the not-for-profit sector observes the aspects that directly challenge labor force such as housing, mobility, and safety. 
"We shouldn't want to bring labor force to Florianopolis because it will also overcrowd the city. We should qualify the many talented people that are already here. We should work on two points: qualifying out talents and bringing strategic people", says one of the interviewees. The public sector points to family allocation related to labor force import, a need raised by both public and private sectors due to a labor shortage and lack of qualified workforce, which is a matter related to skill sets. The academic sector perceives a lack of entrepreneurial training and the public sector points to ideological conflict in entrepreneurship programs.

Overall, educational institutes are highly regarded by the private, public, and academic sectors. In particular, the academic sector perceives opportunities at the Federal University because of the "entrepreneurship spirit", the presence of tech leaders, and the private funding for engineering labs. Despite "resistance to change" from the Federal University, according to the public sector, there is an "engineering strength" as an asset to look at.

The private sector points to challenges due to universities' "walls" and the lack of investment and scholarships. This point of view is aligned with the not-for-profit sector's concern in relation to low investment in science and the lack of relationship between companies and universities. The not-for-profit sector also adds the challenge of turning intangible knowledge into tangible capital, outdated teaching, and lack of living labs. "We are not managing to turn science into innovation", highlights one of the interviewees.

Last, but not least, economic development was the second most cited KBUD dimension among interviewees, with 39 mentions. Overall, the business environment, meaning the context of economic activities developed in the city, as well as its innovation practice, presented the major highlights $(n=29)$, whereas business infrastructure and investment had fewer mentions $(n=10)$, basically pointed out by the public and private sectors.

The public sector understands the city as an asset. The private sector describes Florianópolis as having four main vectors, tourism, civil construction, maritime economy, and ICT, of which all other three helixes, except for the academic sector, affirm that tourism is underdeveloped. On the one hand, the private sector perceives the lack of integration within business context as a challenge, on the other hand, the public sector believes there are too many participatory councils and a shortage of strong brands.

In terms of innovation activity, the private sector helix pointed out that companies' mix minimizes risk, facilitated networking, and provided a high startup density in the city, whereas the public sector helix acknowledged the important role played by the Federal University of Santa Catarina, UFSC in the triple helix origins in the 70s and further development [38].

The consolidation of the innovation environment is perceived by the private sector, and also by the academic and public sectors. One of the representatives of the not-for-profit sector helix understands that "building a more sophisticated science-based cluster, in areas where the issue of science is important as energy and life science is a medium-term challenge".

Nonetheless, there are critics from both the academy and not-for-profit sector helixes. One academy representative says: "It's a city that wants to do everything (...) It wants to innovate, to be a city of events, to be a tourist city ... so it shoots everywhere without a direction". From the not-for-profit sector helix, an interviewee questioned, where the innovation really is by pointing out that "companies here stand out by discipline, technique, growth and applicability, but I can't remember anything that's revolutionary". This respondent realized that "we don't see innovation in the streets" due to the lack of a creative economy: "Great things are content and everyone sells it in this world. We sell tools (...) we do not sell creativeness".

As per business infrastructure, the public sector recognizes institutions CERTI Foundation and ACATE association by playing an important role along with Santa Catarina State's research foundation (FAPESC) for supporting and providing an environment for business. Nevertheless, the private sector identifies there is a lack of capillarity in terms of a "product-led structure not to take big companies, but the startups that today are the basis of the island's innovation, to the world". This leads to another 
aspect for economic development, i.e., investment. Despite the public sector stating there is a lack of private and international investment, the private sector believes it is not about money but collaborative work, "making the quadruple helix rotate". In this sense, "the role of the state is to generate purchase for the national technology-based industry".

\section{Discussion and Conclusions}

This paper applied the KBUD framework in order to shed light on wicked problems that are complex, unclear, interdependent, multi-causal, unpredictable, nonlinear, and dynamic [39]. Research poses that instead of finding the correct answer to a wicked problem, the aim is to achieve a shared understanding of possible solutions [40], which was precisely the reason for studying representatives from the local quadruple helix and their different perspectives.

This study assessed labor force, training/education/institutes, and cultural assets under the KBUD framework's sociocultural dimension. This was supported by the data, as Florianópolis' most cited aspect in the interviews and mostly highly evaluated in the survey. In the latter, half of respondents are aware that the labor force is a major asset and that "creative people attract creative people". Nevertheless, expressions used in the interviews to drive Florianópolis into becoming smarter and more sustainable were the "engineering strength" and the "entrepreneurship spirit" of the Federal University of Santa Catarina. Regardless of the balance between positive and negative remarks on cultural assets in the survey, there is a "contagious innovation culture" in the air, present in both survey and interview. Again, this leads to the observation that not much was referred to on behalf of diversity. For that matter, the city as a whole and the innovation ecosystem will need to think beyond the actual visible trait of gender and race. Creative and responsive solutions are longing for diversity and balancing from different perspectives to face wicked problems.

Labor force imports, due to a shortage of qualified workforce, is also a short-term response to a major demand. A harder and longer-term action is to invest in basic education and training programs. Because it is important to retain the city's talents, it is also important not to lose potential ones to organized crime for lack of investment and opportunities. In this sense, it is relevant to stress that social inequality was mentioned by only two interviewees. In addition, a concern with the increase in safety issues, which is a main consequence of social unbalance, is pointed out as a crucial challenge to creatives' permanence in the city, along with housing and mobility issues. In turn, these aspects belong to the spatial discussion, which was the least cited dimension.

The spatial dimension of the KBUD framework is a major issue in the data, because of Florianópolis' basic infrastructure and territorial planning deficiencies and also for not placing the climate change reality on the agenda. Despite presenting itself as a "green industry", the innovation ecosystem has a lot to adapt to and work towards facing this "glocal" matter, with consequences that deeply affect every sector. It starts by shifting from the utilitarian perspective of nature, which has been granting Florianópolis the title of being a popular tourist destination worldwide for its beaches and seafood, to that of having a responsible engagement with the environment, respecting its geographical limitations. An unfolding to this call can be foreseen in the economic and institutional development dimensions.

This study comprehended governance, partnerships, and support mechanisms as main aspects of the institutional dimension of the KBUD framework. Perceptions, which are considered to be the most challenging area for both survey and interview, are mainly targeted to the public sector's lack of efficiency, accountability, innovation, and continuity of actions. In addition, there is room for perspective change towards the public sector whose aim is to serve the common good and to support the quadruple helix working together in this direction. These liabilities need to be sorted out, as well as social participation beyond the "too many city councils", which are not necessarily addressing the city's aspirations.

Commitment and trust development are key ingredients for this dimension to develop well, which were pointed out as a challenge in the interview, and related to municipal and state collaborative planning and programs' developments. Florianópolis' innovation ecosystem has the potential to thrive, 
despite that the city still has structural issues to deal with, related to the gap between its desire to grow and the acknowledgement from its major actors to support the overall territory to thrive in its complex dimensions. It suggests amplifying the ecosystem's vision, including different sectors and, especially, tackling innovation for the common good [41].

The pressure caused by the growing urbanization generates complex and multifaceted challenges that can only be faced through processes that involve innovation in a shared way. Smart, sustainable, and knowledge-based urbanism approaches can help localities thrive in not only economy and society terms but also spatial and governance wise [42-44].

As a concluding remark, this study was a snapshot of Florianópolis with a focus on the innovation ecosystem reality, an important tool for a transition plan aiming at a more balanced socioecological scenario. It generated useful insights that should help the city retain and inspire more talented and creative people to come and stay, which directly responds to the need for diversity. To keep this on an ongoing basis, in other words sustainability, investment and opportunities must be made in overall education, for all. Here, it goes without saying that as important as it is to develop a strategy plan to boost innovation, basic demands on the socio-environmental front will also need to be acknowledged, analyzed, and addressed in an integrative manner. Therefore, the case study findings reported in this paper are not only useful for the case city Florianópolis, but also invaluable for other cities planning to strategize their transformation, and seeking smart, sustainable, and knowledge-based development pathways in the age of climate, pandemic, and financial catastrophes.

Author Contributions: J.S.-M. and T.Y. designed and supervised the study; T.S., T.W., and D.S. conducted the analysis, and prepared the first full draft of the manuscript; T.I. expanded the manuscript and helped to finalize it by improving its rigor, relevance, and caliber. All authors have read and agreed to the published version of the manuscript.

Funding: The research reported in this paper received funding from industry partners of the Smart Floripa Project, namely the State Government of Santa Catarina, Municipality of Florianópolis, National Confederation of Trade in Goods, Services and Tourism, Senac Santa Catarina.

Acknowledgments: The authors thank anonymous referees for their invaluable comments on an earlier version of the manuscript.

Conflicts of Interest: The authors declare no conflict of interest.

\section{References}

1. Chang, D.L.; Sabatini-Marques, J.; Da Costa, E.M.; Selig, P.M.; Yigitcanlar, T. Knowledge-based, smart and sustainable cities: A provocation for a conceptual framework. J. Open Innov. Technol. Mark. Complex. 2018, 4. [CrossRef]

2. Yigitcanlar, T. Rethinking Sustainable Development: Urban Management, Engineering, and Design; IGI Global: Hersey, PA, USA, 2010.

3. Schmalz, S.; Ebenau, M. After Neoliberalism? Brazil, India, and China in the Global Economic Crisis. Globalizations 2012, 9, 487-501. [CrossRef]

4. Barberia, L.G.; Gómez, E.J. Political and institutional perils of Brazil's COVID-19 crisis. Lancet 2020, 396, 367-368. [CrossRef]

5. Diele-Viegas, L.M.; Pereira, E.J.D.A.L.; Rocha, C.F.D. The new Brazilian gold rush: Is Amazonia at risk? For. Policy Econ. 2020, 119, 102270. [CrossRef]

6. Instituto Brasileiro de Geografia e Estatistica. Estimativas da população residente para os municípios e para as unidades da federação com data de referência em $1^{\circ}$ de julho de 2019: [notas metodológicas]. 2019. Available online: https://biblioteca.ibge.gov.br/index.php/biblioteca-catalogo?view=detalhes\&id=2101662 (accessed on 18 April 2020).

7. Instituto Brasileiro de Geografia e Estatistica. PIB per capita: IBGE, em parceria com os Órgãos Estaduais de Estatística, Secretarias Estaduais de Governo e Superintendência da Zona Franca de Manaus—SUFRAMA. 2017. Available online: https://cidades.ibge.gov.br/brasil/sc/florianopolis/panorama (accessed on 18 April 2020). 
8. Programa de las Naciones Unidas para el Desarrollo; Instituto de Pesquisa Econômica Aplicada; Fair and Just Prosecution. Atlas do Desenvolvimento Humano no Brasil. 2010. Available online: http://atlasbrasil.org. br/2013/pt/perfil_m/florianopolis_sc (accessed on 18 April 2020).

9. Ribeiro, J.M.; Bocasanta, S.L.; Ávila, B.O.; Magtoto, M.; Jonck, A.V.; Gabriel, G.M.; de Andrade, J.B. The adoption of strategies for sustainable cities: A comparative study between Seattle and Florianopolis legislation for energy and water efficiency in buildings. J. Clean. Prod. 2018, 197, 366-378. [CrossRef]

10. Urban Systems. Ranking Connected Smart Cities. 2020. Available online: https://d335luupugsy2.cloudfront. net/cms/files/48668/1599564431Ranking_CSC_2020.pdf (accessed on 14 September 2020).

11. Endeavor Brasil. Índice de Cidades Empreendedoras Brasil. 2017. Available online: https://d335luupugsy2. cloudfront.net/cms/files/6588/1512651268AF-REAL-ICE-2017-web.pdf (accessed on 19 September 2020).

12. Baptista, S.R. Metropolitanization and forest recovery in southern Brazil: A multiscale analysis of the Florianópolis city-region, Santa Catarina State, 1970 to 2005. Ecol. Soc. 2008, 13, 5. [CrossRef]

13. Inkinen, T. Best practices of the Finnish Government Information Society Policy Programme. Transform. Gov. People Process. Policy 2012, 6, 167-187. [CrossRef]

14. Zygiaris, S. Smart City Reference Model: Assisting Planners to Conceptualize the Building of Smart City Innovation Ecosystems. J. Knowl. Econ. 2012, 4, 217-231. [CrossRef]

15. Confortin, S.C.; Antes, D.L.; Pessini, J.; Schneider, I.J.; d'Orsi, E.; Barbosa, A.R. Comparison of sociodemographic profile and health conditions of elderly residents in predominantly rural and urban areas of the Greater Florianópolis, Southern Brazil. Cad. Saúde Coletiva. 2016, 24, 330-338. [CrossRef]

16. Millar, C.C.J.M.; Choi, C.J. Development and knowledge resources: A conceptual analysis. J. Knowl. Manag. 2010, 14, 759-776. [CrossRef]

17. Benneworth, P.; Ratinho, T. Reframing the role of knowledge parks and science cities in knowledge-based urban development. Environ. Plan. C 2014, 32, 784-808. [CrossRef]

18. Yigitcanlar, T.; Dur, F. Making space and place for knowledge communities: Lessons for Australian practice. Australas. J. Reg. Stud. 2013, 19, 36-63.

19. Knight, R.V. Knowledge-based Development: Policy and Planning Implications for Cities. Urban Stud. 1995, 32, 225-260. [CrossRef]

20. Chawla, D.; Joshi, H. Knowledge management practices in Indian industries-A comparative study. J. Knowl. Manag. 2010, 14, 708-725. [CrossRef]

21. Hall, T.; Barrett, H. Urban Geography; Routledge: New York, NY, USA, 2018.

22. Evers, H.D.; Gerke, S.; Menkhoff, T. Knowledge clusters and knowledge hubs: Designing epistemic landscapes for development. J. Knowl. Manag. 2010, 14, 678-689. [CrossRef]

23. Yigitcanlar, T. Australian local governments' practice and prospects with online planning. URISA J. 2006, 18, 7-17.

24. Inkinen, T.; Kaakinen, I. Economic Geography of Knowledge-Intensive Technology Clusters: Lessons from the Helsinki Metropolitan Area. J. Urban Technol. 2016, 23, 95-114. [CrossRef]

25. Hortz, T. The Smart State test: A critical review of the Smart State Strategy 2005-2015's Knowledge-Based Urban Development. Int. J. Knowl. Based Dev. 2016, 7, 75. [CrossRef]

26. Andion, C.; Alperstedt, G.D.; Graeff, J.F. Social innovation ecosystems, sustainability, and democratic experimentation: A study in Florianopolis, Brazil. Rev. Adm. Pública. 2020, 54, 181-200. [CrossRef]

27. De Andrade, J.B.; Ribeiro, J.M.; Fernandez, F.; Bailey, C.; Barbosa, S.B.; da Silva Neiva, S. The adoption of strategies for sustainable cities: A comparative study between Newcastle and Florianópolis focused on urban mobility. J. Clean. Prod. 2016, 113, 681-694. [CrossRef]

28. Kiuru, J.; Inkinen, T. Predicting innovative growth and demand with proximate human capital: A case study of the Helsinki metropolitan area. Cities 2017, 64, 9-17. [CrossRef]

29. Lopez-Saez, P.; Navas-Lopez, J.E.; Martín-de-Castro, G.; Cruz-Gonzalez, J. External knowledge acquisition processes in knowledge-intensive clusters. J. Knowl. Manag. 2010, 14, 690-707. [CrossRef]

30. Mohamed, M.; Murray, A.; Mohamed, M. The role of information and communication technology (ICT) in mobilization of sustainable development knowledge: A quantitative evaluation. J. Knowl. Manag. 2010, 14, 744-758. [CrossRef]

31. Petruzzelli, A.M.; Albino, V.; Carbonara, N.; Rotolo, D. Leveraging learning behavior and network structure to improve knowledge gatekeepers' performance. J. Knowl. Manag. 2010, 14, 635-658. [CrossRef]

32. Graham, S. Telecommunications and the City; Routledge: London, UK, 2002. 
33. Merisalo, M.; Makkonen, T.; Inkinen, T. Creative and knowledge-intensive teleworkers' relation to e-capital in the Helsinki metropolitan area. Int. J. Knowl. Based Dev. 2013, 4, 204. [CrossRef]

34. Inkinen, T.; Merisalo, M.; Makkonen, T. Variations in the adoption and willingness to use e-services in three differentiated urban areas. Eur. Plan. Stud. 2018, 26, 950-968. [CrossRef]

35. Zhao, P. Building knowledge city in transformation era: Knowledge-based urban development in Beijing in the context of globalisation and decentralisation. Asia Pac. Viewp. 2010, 51, 73-90. [CrossRef]

36. Dutta, S.; Reynoso, R.E.; Garanasvili, A.; Saxena, K.; Lanvin, B.; Wunsch-Vincent, S.; Guadagno, F. The Global Innovation Index 2018: Energizing the World with Innovation; Cornell University: Ithaca, NY, USA, 2018.

37. Cabrita, M.D.R.M.F.; Machado, V.; Cabrita, C. Managing creative industries in the context of knowledge-based urban development. Int. J. Knowl. Based Dev. 2013, 4, 318. [CrossRef]

38. Gohari, S.; Medalen, T.; Aranya, R. Exploring the Impact of Complex Multi-Level Governance Structures on the Societal Contribution of Universities to Knowledge-Based Urban Development. Soc. Sci. 2019, 8, 279. [CrossRef]

39. Levin, K.; Cashore, B.; Bernstein, S.; Auld, G. Overcoming the tragedy of super wicked problems: Constraining our future selves to ameliorate global climate change. Policy Sci. 2012, 45, 123-152. [CrossRef]

40. Conklin, J. Wicked Problems and Social Complexity. In Dialogue Mapping: Building Shared Understanding of Wicked Problems; Wiley: New York, NY, USA, 2006.

41. Florida, R.; Adler, P.; Mellander, C. The city as innovation machine. Reg. Stud. 2016, 51, 86-96. [CrossRef]

42. Yigitcanlar, T.; Kamruzzaman, M. Planning, development and management of sustainable cities: A commentary from the guest editors. Sustainability 2015, 7, 14677-14688. [CrossRef]

43. Alvarez, M.D. Creative cities and cultural spaces: New perspectives for city tourism. International. J. Cult. Tour. Hosp. Res. 2010, 4, 171-175. [CrossRef]

44. Martin, C.J.; Evans, J.; Karvonen, A. Smart and sustainable? Five tensions in the visions and practices of the smart-sustainable city in Europe and North America. Technol. Forecast. Soc. Chang. 2018, 133, 269-278. [CrossRef]

Publisher's Note: MDPI stays neutral with regard to jurisdictional claims in published maps and institutional affiliations.

(C) 2020 by the authors. Licensee MDPI, Basel, Switzerland. This article is an open access article distributed under the terms and conditions of the Creative Commons Attribution (CC BY) license (http://creativecommons.org/licenses/by/4.0/). 